\title{
PENGARUH PENERAPAN RESTRUKTURISASI ORGANISASI, PEMANFAATAN TEKNOLOGI INFORMASI DAN KOMUNIKASI SERTA PENYEMPURNAAN SUMBER DAYA MANUSIA TERHADAP KEPATUHAN WAJIB PAJAK
}

\author{
Samsul Huda ${ }^{{ }^{*}}$ \\ ${ }^{1}$ Program Magister Akuntansi, Pascasarjana FEB, Universitas Brawijaya Malang \\ *samsalhada@yahoo.com
}

\begin{abstract}
The objective of research is to provide empirical evidence about the effect of organizational restructuring practice, information and communication technology utilization, and human resource perfection on the obedience of private taxpayers at Pratama Tax Service Office of North Malang. Method of research is quantitative with survey subjected to Private Taxpayers (WPOP) who effectively registered at Pratama Tax Service Office of North Malang. Data analysis is using Structural Equation Modeling (SEM). Result of research showed empirical evidence that organizational restructuring practice was influential to or brought an impact on the increasing obedience among taxpayers. The best indicator to this variable was Internal Audit. Information and Communication Technology Utilization is influential to or delivered an impact on the increase of taxpayers' obedience. The best indicator of this variable is Information Technology Based. Human resource perfection is influential to or impacting on the increasing obedience of taxpayers. The best indicator of this variable was Customer Driven. Some theories are used to support the explanation about taxpayers' obedience. Among these included Planned Behavior Theory and Fiscal Psychology Theory. Both theories perceived that the policy made by the government as the holder of tax authority, and the attitude and perception of taxpayers, similarly played important role to increase taxpayers' obedience.
\end{abstract}

Keywords: Organizational Restructuring Practice, Information and Communication Technology Utilization, Human Resource Perfection.

\section{PENDAHULUAN}

Perpajakan adalah merupakan salah satu instrumen kebijakan fiskal yang dinamis, penerapannya harus senantiasa mengikuti dinamika perekonomian, baik domestik maupun internasional. Penerimaan dari sektor pajak diharapkan mampu mengurangi ketergantungan pada utang luar negeri serta mampu membangkitkan kembali kepercayaan diri bangsa Indonesia. Ini selaras dengan misi yang diemban oleh Direktorat Jenderal Pajak selaku pemegang kewenangan kebijakan perpajakan yang berkompeten di negeri ini, yaitu mengumpulkan pajak sebagai penerimaan negara terbesar sebagai penunjang pembangunan dan kemandirian pembiayaan APBN. Namun kenyataan yang terjadi saat ini adalah tingkat kepatuhan wajib pajak masih belum sesuai dengan yang diharapkan.

Mengingat begitu pentingnya kepatuhan wajib pajak terhadap peningkatan penerimaan pajak, maka perlu dikaji secara intensif tentang faktor-faktor yang mempengaruhi kepatuhan wajib pajak (Mustikasari, 2007), terutama bagi wajib pajak badan. Hal ini dikarenakan bahwa selama ini penerimaan pajak dari wajib pajak 
penghasilan telah memberikan kontribusi terbesar terhadap jumlah keseluruhan penerimaan jenis pajak di Indonesia. Oleh karena itu, penting untuk dikaji mengenai faktor-faktor yang mempengaruhi kepatuhan wajib pajak, karena dengan diketahuinya faktor-faktor yang mempengaruhi kepatuhan wajib pajak, pemerintah dapat menciptakan lingkungan yang mendukung terciptanya kepatuhan pajak.

Berkaitan dengan Undang-undang dan peraturan pajak, administrasi pajak dan kebijakan pajak, Gunadi (2004) menyatakan bahwa penyebab tax gap adalah peraturan perpajakan $(0,02 \%)$, kebijakan perpajakan (45,89\%), dan administrasi perpajakan (54,2\%) dimana administrasi perpajakan berpengaruh paling besar terhadap tax gap. Hal ini senada dengan Suandy (2003) yang menyatakan terdapat tiga unsur perpajakan yaitu peraturan pajak, kebijakan pajak dan administrasi pajak. Dengan substansi yang dikembangkan terbatas pada penerapan sistem administrasi perpajakan modern sebagai praktik reformasi administrasi perpajakan, penelitian ini dimaksudkan untuk mengetahui sejauh mana penerapan sistem administrasi perpajakan modern dalam kerangka reformasi administrasi perpajakan jangka menengah yang telah digulirkan oleh Direktorat Jenderal Pajak sejak tahun 2001 pada Kantor Pelayanan Pajak Malang Utara serta menelaah pengaruhnya terhadap kepatuhan wajib pajak. Salah satu faktor yang mempengaruhi optimalisasi penerimaan pajak adalah administrasi pajak. Administrasi perpajakan merupakan hal yang penting untuk mendorong wajib pajak memenuhi kewajiban perpajakannya, karena administrasi perpajakan berkaitan dengan kelengkapan instruksi dan kerumitan formulir (Hardika, 2006).

Penelitian ini bertujuan untuk menguji pengaruh penerapan sistem administrasi perpajakan modern terhadap kepatuhan wajib pajak, dengan variabel bebas yaitu; restrukturisasi organisasi, pemanfaatan teknologi informasi dan penyempurnaan sumber daya manusia. Sedangkan variabel terikat adalah kepatuhan wajib pajak dengan populasi dan sampel wajib pajak orang pribadi. Objek penelitian ini adalah wajib pajak orang pribadi di KPP Malang Utara. Pemilihan KPP Malang Utara dikarenakan pada tahun 2015 Kantor Wilayah Jawa Timur III realisasi penerimaan pajak 2015 menembus angka Rp 19,6 triliun atau 91,55\% dari target penerimaan sebesar Rp 21,4 triliun, sedangkan KPP Malang Utara adalah salah satu diantara diantara 14 KPP dibawah Koordinasi Kanwil Jatim III dengan total penerimaan $\mathrm{Rp}$ 433.424.643.610 dari target Rp 441.675.391.999 atau 98\% pada tahun 2015. Keberhasilan ini tentunya menarik untuk diteliti dari sisi reformasi administrasi perpajakan terutama terkait restrukturisasi organisasi, pemanfaatan teknologi informasi dan komunikasi serta penyempurnaan sumber daya manusia bila dihubungkan dengan kepatuhan wajib pajak.

\section{Restrukturisasi Organisasi}

Menurut Pandiangan

restrukturisasi organisasi adalah aktivitas yang dilakukan organisasi untuk merubah proses dan kendali internalnya dari suatu hirarki vertikal fungsional yang tradisional, menjadi struktur pipih yang horizontal, lintas fungsional dengan berlandaskan kerjasama tim yang berfokus pada proses dapat membuat organisasi lebih nyaman. Dalam hal ini organisasi ditata kembali agar menjadi organisasi yang open manajemen, yaitu organisasi yang responsive dan adaptif terhadap perubahan, maupun menunjang kelancaran operasional, memiliki fleksibelitas yang tinggi, mampu melaksanakan pengendalian dan meningkatkan akuntabilitas.

Perubahan ini bertujuan untuk menyederhanakan pola administrasi perpajakan yang berorientasi pada pelayanan dan pengawasan yang modern. Indikatorindikator yang digunakan dalam penelitian ini berdasarkan penelitian yang telah dilakukan penelitian terdahulu yang menunjukkan jika indikator-indikator tersebut dapat mewakili restrukturisasi organisasi sebagai bagian dari modernisasi sistem perpajakan yang akan diteliti 
pengaruhnya terhadap kepatuhan wajib pajak.

\section{Pemanfaatan Teknologi Informasi}

Menurut Suyanto (2005) pemanfaatan teknologi informasi adalah merujuk pada seluruh bentuk teknologi yang digunakan untuk menciptakan, menyimpan, mengubah, dan menggunakan informasi dalam segala bentuknya. Organisasi sektor publik dinilai mengalami ketertinggalan dibanding sektor swasta dalam pengembangan, implementasi dan tata kelola TI (Caudle et.al) dalam (Jogiyanto, 2011). Dengan demikian perlu dilakukan peningkatan pemanfaatan teknologi informasi dan komunikasi sehingga hal ini menjadi salah satu aspek dalam modernisasi sistem perpajakan yang harus diperhatikan.

Hasil penelitian Rahayu dan Lingga (2009) menunjukkan jika pemanfaatan teknologi informasi dan komunikasi sebagai bagian dari modernisasi system administrasi perpajakan secara positif dan signifikan mempengaruhi kepatuhan wajib pajak bahkan dari hasil penelitian Palupi (2010) diketahui jika pemanfaatan teknologi informasi dan komunikasi memberikan pengaruh paling dominan terhadap tingkat kepatuhan wajib pajak. Lebih lanjut hasil penelitian Artiningsih (2013) menunjukkan jika pelayanan perpajakan berpengaruh secara signifikan terhadap tingkat kepatuhan wajib pajak di KPP Pratama Sleman, dimana guna memberikan pelayanan perpajakan yang optimal maka perlu pemanfaatan teknologi informasi dan komunikasi sehingga pelayanan yang diberikan bisa lebih mudah dan lebih cepat

\section{Penyempurnaan Sumber Daya Manusia}

Bagi sektor publik, tanggung jawab besar birokrasi dalam memberi pelayanan kepada masyarakat harus didukung oleh Sumber Daya Manusia (SDM) aparatur yang profesional dan kompeten. Dalam konteks reformasi birokrasi, Penyempurnaan SDM merupakan salah satu pilar perbaikan di samping aspek kelembagaan dan system. Menurut Pandiangan (2008) penyempurnaan sumber daya manusia adalah merupakan bagian dari modernisasi sistem administrasi perpajakan yang harus dilakukan oleh Direktorat Jenderal Pajak.

Lebih lanjut Kristina (2009) mengemukakan jika penyempurnaan Sumber Daya Manusia merupakan kunci utama keberhasilan reformasi dimanapin elemen terpenting dalam organisasi ialah terletak pada sumber daya manusianya. Secanggih ataupun sehebat apapun organisasi kalau tidak didukung dan diisi dengan sumber daya manusia yang mumpuni/capable dan berintegritas tinggi maka lambat laun organisasi tersebut akan hancur dan tujuan organisasi tersebut tidak akan tercapai.

\section{Kepatuhan Wajib Pajak}

Menurut Toggler (2007) bahwa kepatuhan pajak merupakan fenomena sosial yang sukar untuk digambarkan. Untuk memahami efek dari sistem pajak perlu diketahui orang-orang yang patuh dan yang tidak patuh dengan hukum pajak. Kepatuhan wajib pajak (tax compliance) dapat diidentifikasi dari kepa-tuhan wajib pajak dalam mendaftarkan diri, kepatuhan untuk menyetorkan kem-bali surat pemberitahuan (SPT), kepatuh-an dalam penghitungan dan pembayaran pajak terutang, dan kepatuhan dalam pembayaran tunggakan.

Dalam upaya meningkatkan kepatuhan wajib pajak, pemerintah melakukan modernisasi sistem adminis-trasi perpajakan (Mentayani, Rusmanto dan Mail. 2015). Sedangkan menurut Nasucha (2004) ada beberapa indikator dari kepatuhan wajib pajak, diantaranya ialah keinginan wajib pajak mendaftarkan diri, ketepatan dalam pelaporan, ketepatan menghitung pajak terhutang dan kesediaan membayar denda

\section{Pengembangan Hipotesis}

Hipotesis dalam penelitian ini terdiri dari tiga hipotesis yang digambarkan dalam kerangka model penelitian seperti pada Gambar 1. 


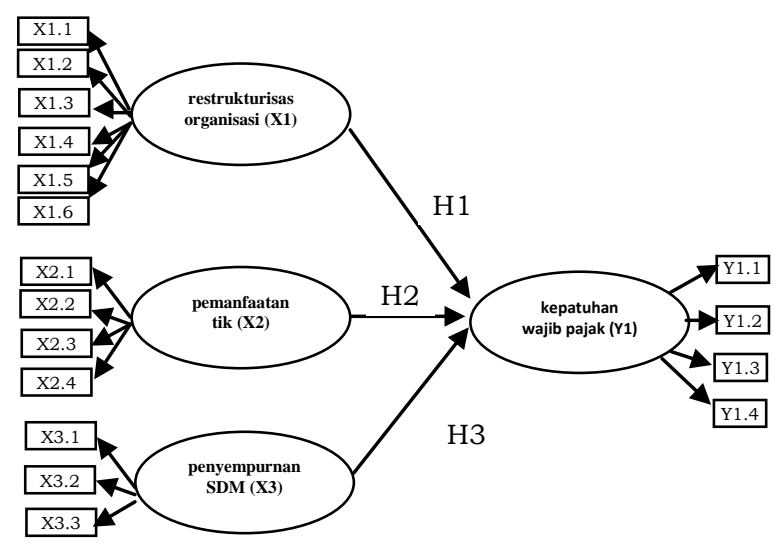

Gambar 1. Kerangka Model Penelitian

\section{Pengaruh Restrukturisasi Organi-sasi} Terhadap Kepatuhan Wajib Pajak

Struktur organisasi yang telah berubah berdasarkan fungsi merupakan salah satu cara untuk penerapan sistem administrasi modern. Dengan adanya modernisasi struktur organisasi kerja yang lebih baik seperti pembentukan organisasi berdasarkan fungsi dan bukan lagi pada jenis pajak, spesifikasi tugas dan tanggung jawab seperti adanya bagian pengawasan, penagihan dan pemeriksaan dimana jalur pengawasan tugas pelayanan dan pemeriksaan akan memudahkan wajib pajak dalam melaporkan pajaknya sehingga kepatuhan wajib pajak akan meningkat (Candra dkk, 2013). Hasil penelitian Masyur (2013) dan Candra dkk (2013) menunjukkan pengaruh positif signifikan antara restrukturisasi organisasi terhadap kepatuhan wajib pajak. Dengan demikian hipotesis yang dapat dirumuskan adalah:

H1: Restrukturisasi Organisasi berpengaruh positif terhadap kepatuhan wajib pajak

\section{Pengaruh pemanfaatan teknologi informasi dan komunikasi terhadap kepatuhan wajib pajak}

Pemanfaatan teknologi informasi dan komunikasi sebagai salah satu focus dalam modernisasi system administrasi perpajakan pada dasarnya adalah untuk memberikan pelayanan yang optimal pada wajib pajak sehingga proses administrasi perpajakan dan pelayanan terhadap wajib pajak bisa lebih cepat, mudah dan akurat dan diharapkan dapat meningkatkan kepatuhan pajak. Hasil penelitian Palupi (2010) membuktikan bahwa teknologi informasi berpengaruh terhadap kepatuhan wajib pajak. Hal ini didukung oleh penelitian yang dilakukan Widayati dan Nurlis (2010) yang menemukan jika persepsi yang baik atas efektivitas sistem perpajakan menjadi salah satu faktor yang mempengaruhi kemauan membayar pajak. Dapat dikemukakan jika untuk meningkatkan efektivitas sistem perpajakan dapat dilakukan dengan memanfaatkan teknologi informasi dan komunikasi dengan harapan akan meningkatkan kepatuhan wajib pajak dalam melaksanakan kewajibannya. Berdasarkan hal tersebut dapat dikemukakan jika pemanfaatan teknologi informasi dan komunikasi berpengaruh positif terhadap kepatuhan wajib pajak. Dengan demikian hipotesis yang dapat dirumuskan adalah:

H2: Pemanfaatan Teknologi Informasi dan Komunikasi berpengaruh positif terhadap kepatuhan wajib pajak.

\section{Pengaruh penyempurnaan sumber daya manusia terhadap kepatuhan wajib pajak}

Sebuah instansi harus didukung sumber daya manusia yang cakap karena sumber daya manusia sangat berperan dalam menjalankan usaha atau kegiatan di dalam instansi tersebut. Sehebat apapun struktur organisasi, manajemen, teknologi informasi, metode dan alur kerja dalam suatu organisasi, semua hal tersebut tidak akan dapat berjalan optimal tanpa didukung dengan adanya sumber daya manusia yang berkualitas dan berintegritas. Subiyantoro dalam (Palupi, 2010) bahwa upaya penyiapan sumber daya manusia (SDM) yang berkualitas dan professional adalah bagian dari program reformasi aspek sumber daya manusia, yang dilakukan melalui pelaksanaan fit and proper test secara ketat, penempatan pegawai sesuai kapasitas dan kapabilitasnya, reorganisasi, kaderisasi, pelatihan dan program pengembangan self capacity. Hal ini dilakukan dengan tujuan untuk meningkatkan kompetensi pegawai Direktorat Jenderal Pajak dalam memberikan pelayanan pada wajib pajak sehingga dapat meningkatkan 
kepatuhan wajib pajak. Berdasarkan hasil dari penelitian yang dilakukan oleh Palupi (2010) menunjukkan jika penyempurnaan sumber daya manusia berpengaruh positif dan signifikan terhadap kepatuhan wajib pajak. Dengan demikian maka dapat dikemukakan hipotesis adalah:

H3: Penyempurnaan Sumber Daya Manusia berpengaruh positif terhadap kepatuhan wajib pajak.

\section{METODE}

Penelitian ini menggunakan metode penelitian kuantitatif.Metode kuantitatif berlandaskan pada realitas dipandang sebagai sesuatu yang kongkrit, dapat diamati dengan panca indera, dapat dikategorikan menurut jenis, bentuk, dan perilaku, tidak berubah, dapat diukur dan diverifikasi (Sugiyono, 2012). Sedangkan pendekatan yang dilakukan dalam penelitian ini menggunakan pendekatan survey.

Populasi pada penelitian ini adalah Wajib Pajak Orang Pribadi (WPOP) efektif yang terdaftar di Kantor Pelayanan Pajak Pratama (KPP) Malang Utara sebanyak 63.610 orang. Jumlah sampel ditentukan dengan menggunakan rumus Slovin sebanyak 398 responden. Metode pengambilan sampel yang digunakan dalam penelitian ini adalah purposive sampling, yaitu teknik penentuan sampel dalam pertimbangan tertentu (Sugiyono, 2012) yaitu Wajib pajak di KPP Malang Utara dengan batasan minimal telah menjadi wajib pajak selama \pm 3 tahun dan merupakan wajib pajak yang aktif melakukan pelaopran dan pembayaran $\mathrm{PPh}$ sehingga dapat mengetahui proses pelayanan yang diberikan berhubungan dengan moderinsasi administrasi perpajakan dan tingkat kepatuhan wajib pajak yang bersangkutan serta Wajib pajak yang dimaksud merupakan wajib pajak orang pribadi.

Sumber data yang digunakan dalam penelitian ini merupakan data primer.Data primer merupakan data yang diperoleh langsung dari obyek penelitian yaitu para wajib pajak $\mathrm{PPh}$ orang pribadi di Kantor
PelayananPajak Pratama Malang Utara melalui kuesioner.

Proses analisis data dalam penelitian dilakukan dengan Structural Equation Modeling (SEM). Structural Equation Modeling (SEM) merupakan suatu teknik statistika yang melakukan pengujian sebuah rangkaian hubungan yang relatif rumit dan secara simultan. Hubungan itu dapat dibangun antara satu atau beberapa variabel tergantung dengan satu atau beberapa variabel independen dan dapat berbentuk faktor atau konstruksi, yang dibangun dari beberapa variabel indikator. Variabelvariabel itu dapat berbentuk sebuah variabel tunggal yang diobservasi atau diukur secara langsung.

Respon rate responden dalam penelitian ini sebesar $81.26 \%$ dengan rincian data kuesioner dari 507 kuesioner yang disebar terdapat 422 kuesioner kembali dan bisa dianalisis sebanyak 398. Karakteristik responden untuk jenis kelamin tidak berbeda jauh menunjukkan jika baik laki-laki maupun perempuan mempunyai kesadaran yang sama untuk membayar pajak pribadi. Dari segi usia didominasi responden yang berusia 26 tahun sampai 35 tahun (36.9\%), hal ini menunjukkan jika mayoritas wajib pajak pribadi di KPP Pratama Malang Utara berada dalam usia produktif yang mempunyai pendapatan cukup besar serta mempunyai kesadaran untuk membayar pajak pribadinya. Berdasarkan latar belakang pendidikan didominasi pendidikan Strata 1 (S1) yaitu 57\%. Berdasarkan penyiapan SPT didominasi responden menyiapkan SPT nya sendiri, menunjukkan kesadaran para wajib pajak pribadi membayar pajak cukup tinggi dengan menyiapkan laporannya sendiri.

\section{HASIL DAN PEMBAHASAN}

Pengujian validitas menggunakan teknik Product moment dari Perarson dilakukan dengan mengkorelasikan tiap skor item dengan skor total. Kriteria pengujian adalah jika suatu item dinyatakan valid dan dinyatakan sah sebagai alat pengumpul data jika indeks korelasi product moment pearson (r) $\geq 0,3$. 
Berdasarkan hasil uji validitas, diketahui bahwa seluruh item pertanyaan pada variabel yang diteliti memiliki nilai koefisien validitas lebih besar dari nilai kritis $(0,300)$. Maka seluruh item pada variabel yang diteliti dapat dilanjutkan untuk analisis selanjutnya.

Pengujuan reliabilitas untuk mengujur sejauh mana tingkat kekonsistenan pengukuran atau dengan kata lain sejauh mana pertanyaan dapat difahami sehingga tidak menyebabkan beda interpretasi dalam pemahaman pertanyaan tersebut. Dikatakan reliabel jika koefisien reliabilitasnya lebih besar atau sama dengan 0,700.

Tabel 1. Uji Reliabilitas

\begin{tabular}{cccc}
\hline $\begin{array}{c}\text { Variab } \\
\text { el }\end{array}$ & $\begin{array}{c}\text { Indeks } \\
\text { Reliabilit } \\
\text { as }\end{array}$ & $\begin{array}{c}\text { Nilai } \\
\text { Kritis }\end{array}$ & $\begin{array}{c}\text { Keteranga } \\
\mathbf{n}\end{array}$ \\
\hline $\begin{array}{c}\mathrm{RO} \\
\left(\mathrm{X}_{1}\right)\end{array}$ & 0,903 & 0,700 & Reliabel \\
\hline $\begin{array}{c}\mathrm{TIK} \\
\left(\mathrm{X}_{2}\right)\end{array}$ & 0,908 & 0,700 & Reliabel \\
\hline $\begin{array}{c}\mathrm{SDM} \\
\left(\mathrm{X}_{3}\right)\end{array}$ & 0,858 & 0,700 & Reliabel \\
\hline $\begin{array}{c}\mathrm{KWP} \\
(\mathrm{Y})\end{array}$ & 0,916 & 0,700 & Reliabel \\
\hline
\end{tabular}

Sumber : data diolah

Hasil nilai koefisien reliabilitas untuk masing-masing variabel $>$ nilai kritis $(0,700)$, sehingga seluruh variabel penelitian dinyatakan reliabel.

\section{Uji Ketepatan Model}

Uji kecocokan model berkaitan dengan analisis terhadap GOF statistik yang dihasilkan oleh program, dalam hal ini AMOS 20. Dengan menggunakan pedoman ukuran GOF dan hasil GOF statistic, maka analisis kecocokan keseluruhan model sebagai berikut:
Tabel 2. Evaluasi Kecocokan Model Struktural (Sebelum modifikasi Model)

\begin{tabular}{|c|c|c|c|}
\hline $\begin{array}{c}\text { Goodness } \\
\text { of fit } \\
\text { Index }\end{array}$ & $\begin{array}{l}\text { Cut of } \\
\text { value }\end{array}$ & Hasil & Keterangan \\
\hline $\begin{array}{l}\text { Chi- } \\
\text { Square }\end{array}$ & $<138,811$ & $\begin{array}{c}100,14 \\
3\end{array}$ & $\begin{array}{c}\text { Model } \\
\text { Good Fit }\end{array}$ \\
\hline $\begin{array}{c}\text { Probabili } \\
\text { ty }\end{array}$ & $>0,050$ & 0,801 & $\begin{array}{c}\text { Model } \\
\text { Good Fit }\end{array}$ \\
\hline $\begin{array}{c}\text { CMIN/ } \\
\text { DF }\end{array}$ & $<2,000$ & 0,886 & $\begin{array}{l}\text { Model } \\
\text { Good Fit }\end{array}$ \\
\hline $\begin{array}{c}\text { RMSE } \\
\text { A }\end{array}$ & $<0,080$ & 0,000 & $\begin{array}{l}\text { Model } \\
\text { Good Fit }\end{array}$ \\
\hline GFI & $>0,900$ & 0,971 & $\begin{array}{l}\text { Model } \\
\text { Good Fit }\end{array}$ \\
\hline AGFI & $>0,900$ & 0,961 & $\begin{array}{l}\text { Model } \\
\text { Good Fit }\end{array}$ \\
\hline CFI & $>0,950$ & 1,000 & $\begin{array}{l}\text { Model } \\
\text { Good Fit }\end{array}$ \\
\hline
\end{tabular}

Sumber : data diolah

Pada tabel di atas menunjukkan bahwa model SEM yang dikonstruksikan dinyatakan layak dan dapat diterima.

\section{Model pengukuran (Measurement Model)}

Measurement model merupakan model dengan hasil perhitungan berdasarkan perhitungan menggunakan program AMOS 20 dengan Confirmatory Factor Analysis. Tujuan model pengukuran (measurement model) adalah untuk menggambarkan sebaik apa indikator-indikator di dalam penelitian ini dapat digunakan sebagai instrumen pengukuran variabel laten.

Tabel 3. Model Pengukuran

\begin{tabular}{|c|c|c|c|c|}
\hline \multirow{3}{*}{$\begin{array}{l}\text { Variabe } \\
\text { I Laten }\end{array}$} & \multirow{3}{*}{$\begin{array}{c}\text { Variabel } \\
\text { Teramati }\end{array}$} & \multicolumn{2}{|c|}{ Validitas } & \multirow{3}{*}{ 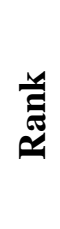 } \\
\hline & & \multicolumn{2}{|c|}{ (LF $>0,5=$ Valid $)$} & \\
\hline & & $\begin{array}{c}\text { Loading } \\
\text { Factors }\end{array}$ & Ket & \\
\hline \multirow{6}{*}{$\begin{array}{l}\text { RO } \\
\text { (X1) }\end{array}$} & X11 & 0,801 & Valid & 2 \\
\hline & $\mathrm{X} 12$ & 0,763 & Valid & 3 \\
\hline & X13 & 0,691 & Valid & 5 \\
\hline & X14 & 0,701 & Valid & 4 \\
\hline & X15 & 0,811 & Valid & 1 \\
\hline & X16 & 0,698 & Valid & 2 \\
\hline TIK & $\mathrm{X} 21$ & 0,914 & Valid & 1 \\
\hline (X2) & X22 & 0,664 & Valid & 4 \\
\hline
\end{tabular}




\begin{tabular}{|c|c|c|c|c|}
\hline \multirow{3}{*}{$\begin{array}{l}\text { Variabe } \\
\text { l Laten }\end{array}$} & \multirow{3}{*}{$\begin{array}{l}\text { Variabel } \\
\text { Teramati }\end{array}$} & \multicolumn{2}{|c|}{ Validitas } & \multirow{3}{*}{ 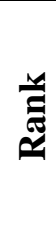 } \\
\hline & & \multicolumn{2}{|c|}{ (LF $>0,5=$ Valid) } & \\
\hline & & $\begin{array}{l}\text { Loading } \\
\text { Factors }\end{array}$ & Ket & \\
\hline & X23 & 0,709 & Valid & 3 \\
\hline & X24 & 0,859 & Valid & 2 \\
\hline \multirow{3}{*}{$\begin{array}{l}\text { SDM } \\
\text { (X3) }\end{array}$} & X31 & 0,806 & Valid & 3 \\
\hline & X32 & 0,842 & Valid & 1 \\
\hline & X33 & 0,817 & Valid & 2 \\
\hline \multirow{4}{*}{$\begin{array}{c}\text { KWP } \\
\text { (Y1) }\end{array}$} & Y11 & 0,806 & Valid & 3 \\
\hline & Y12 & 0,759 & Valid & 4 \\
\hline & Y13 & 0,862 & Valid & 1 \\
\hline & Y14 & 0,853 & Valid & 2 \\
\hline
\end{tabular}

Sumber : data diolah

Berdasarkan tabel di atas dapat diketahui faktor kunci yang dominan dalam memberikan kontribusi terhadap konstruk laten dapat dijelaskan bahwa indikator yang paling baik dalam membentuk variabel Restrukturisasi Organisasi $\left(\mathrm{X}_{1}\right)$ adalah $\mathrm{X}_{15}$ (Internal Audit) dengan loading faktor tertinggi $(0,811)$. Indikator yang paling baik dalam membentuk variabel Pemanfaatan TIK $\left(\mathrm{X}_{2}\right)$ adalah $\mathrm{X}_{21}$ (Berbasis Teknologi Informasi) dengan loading faktor tertinggi $(0,914)$. Indikator yang paling baik dalam membentuk variabel Penyempurnaan SDM $\left(\mathrm{X}_{3}\right)$ adalah $\mathrm{X}_{32}$ (Customer Driven) dengan loading faktor tertinggi $(0,842)$ dan indikator yang paling baik dalam membentuk variabel Kepatuhan Wajib Pajak $\left(\mathrm{Y}_{1}\right)$ adalah $\mathrm{Y}_{13}$ (Perhitungan dan Pembayaran Pajak Terutang) dengan loading faktor tertinggi $(0,862)$.

\section{Model Struktural}

Bagian ini berhubungan dengan evaluasi terhadap koefisien-kofisien atau parameter-parameter yang menunjukkan hubungan kausal atau pengaruh satu variabel laten terhadap variabel laten lainnya. Sebuah hubungan kausal dinyatakan tidak signifikan jika nilai critical ratio (C.R.) berada diantara rentang -1.96 dan 1.96 dengan tingkat signifikansi 0,05.
Tabel 4. Hasil Estimasi dan Pengujian Hipotesis

\begin{tabular}{|c|c|c|c|c|c|c|}
\hline & Irial & bel & Koef & $\begin{array}{l}\text { Ha } \\
\text { Hip }\end{array}$ & $\begin{array}{l}\text { il Uji } \\
\text { otesis }\end{array}$ & $\begin{array}{l}\text { Kesim } \\
\text {-pulan }\end{array}$ \\
\hline Eksoger & & Endogen & & CR & $p$-value & \\
\hline $\begin{array}{c}\mathrm{RO} \\
(\mathrm{X} 1)\end{array}$ & $\rightarrow$ & $\begin{array}{l}\text { KWP } \\
\text { (Y1) }\end{array}$ & 0,254 & 4,082 & 0,000 & Sig \\
\hline $\begin{array}{l}\text { TIK } \\
\text { (X2) }\end{array}$ & $\rightarrow$ & $\begin{array}{c}\text { KWP } \\
\text { (Y1) }\end{array}$ & 0,447 & 6,043 & 0,000 & Sig \\
\hline $\begin{array}{l}\text { SDM } \\
\text { (X3) }\end{array}$ & $\rightarrow$ & $\begin{array}{c}\text { KWP } \\
\text { (Y1) }\end{array}$ & 0,358 & 5,388 & 0,000 & Sig \\
\hline
\end{tabular}

Sumber : data diolah

Guna memudahkan evaluasi outer model yang sekaligus terintegrasi dengan analisis jalur (path analysis), berikut disajikan diagram jalur model pengukuran (outer model) dan model struktural (structural model) sebagaimana gambar di bawah ini.

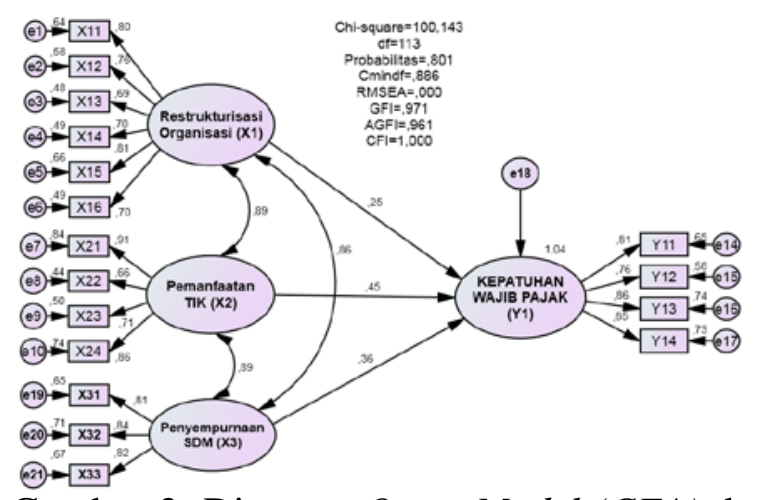

Gambar 2. Diagram Outer Model (CFA) dan Structural Model (Path)

Berdasarkan tabel dan gambar diatas dapat diketahui hasil estimasi dan pengujian hipotesis sebagai berikut:

Variabel Restrukturisasi Organisasi (X1) memiliki pengaruh (koefisien Jalur) terhadap Kepatuhan Wajib Pajak (Y1) = 0,254 dengan nilai $\mathrm{CR}=4,082$ dan p-value sebesar 0 . Karena nilai CR berada pada rentang -1.96 dan 1.96 serta nilai p-value < 0,05, maka Ho ditolak, artinya Restrukturisasi Organisasi (X1) berpenga-ruh signifikan terhadap Kepatuhan Wajib Pajak (Y1). Maka hipotesis I yang menyatakan bahwa restrukturisasi organisasi berpengaruh positif terhadap kepatuhan wajib pajak terpenuhi.

Variabel Pemanfaatan TIK (X2) memiliki pengaruh (koefisien Jalur) terhadap 
Kepatuhan Wajib Pajak $(\mathrm{Y} 1)=0,447$ dan nilai $\mathrm{CR}=6,043$ dan $\mathrm{p}$-value sebesar 0 . Karena nilai CR berada pada rentang -1.96 dan 1.96 serta nilai $\mathrm{p}$-value $<0,05$, maka Ho ditolak, artinya Pemanfaatan TIK (X2) berpengaruh signifikan terhadap Kepatuhan Wajib Pajak (Y1). Dengan demikian hipotesis II yang menyatakan bahwa pemanfaatan Teknologi Informasi dan Komunikasi berpengaruh positif terhadap kepatuhan wajib pajak terpenuhi.

Variabel Penyempurnaan SDM (X3) memiliki pengaruh (koefisien Jalur) terhadap Kepatuhan Wajib Pajak (Y1) = 0,358 dengan nilai $\mathrm{CR}=5,388$ dan $\mathrm{p}$-value sebesar 0 . Karena nilai CR berada pada rentang -1.96 dan 1.96 serta nilai p-value $<0,05$, maka Ho ditolak, artinya Penyempurnaan SDM (X3) berpengaruh signifikan terhadap Kepatuhan Wajib Pajak (Y1). Dengan demikian hipotesis III yang menyatakan bahwa penyempurnaan sumber daya manusia berpengaruh positif terhadap kepatuhan wajib pajak terpenuhi.

Guna mengetahui kontribusi semua variabel eksogen (restrukturisasi orga-nisasi, pemanfaatan teknologi dan informasi serta penyempurnaan sumber daya manusia) terhadap variabel endogen yaitu kepatuhan wajib pajak dalam analisis SEM dapat diketahui dari koefisien GFI (Goodness of Fit Index). GFI (Goodness of Fit Index) analog dengan koefisien determinasi ( $\mathrm{R}$ Square) dalam analisis regresi berganda. Berdasarkan hasil analisis diperoleh koefisien GFI sebesar 0.971 menunjukkan jika model yang didapatkan mampu menjelaskan pengaruh antara variabel-variabel restrukturisasi organisasi, pemanfaatan teknologi dan informasi serta penyempurnaan sumber daya manusia terhadap kepatuhan wajib pajak sebesar $97.1 \%$ dan disanya sebesar $2.9 \%$ dipengaruhi oleh variabel lain yang tidak diamati dalam penelitian ini.

\section{Pengaruh Restrukturisasi Organisasi terhadap Kepatuhan Wajib Pajak}

Restrukturisasi organisasi merupakan perubahan yang dilakukan dengan melakukan perubahan secara struktural yaitu perubahan tanggungjawab dan wewenang. Perubahan ini bertujuan untuk menyederhanakan pola adminis-trasi perpajakan yang berorientasi pada pelayanan dan pengawasan yang modern. Dengan adanya restrukturisasi organisasi ini diharapkan strategi dan pendekatan pola pelayanan dapat disesuaikan dengan karakteristik wajib pajak yang ditangani sehingga dapat memberikan pelayanan yang lebih optimal. Selain itu dengan restrukturisasi organisasi yang memisahkan fungsi pemeriksaan dan fungsi keberatan membuat kinerja dalam DJP dapat lebih efektif.

Berdasarkan hasil analisis diketahui bahwa restrukturisasi organisasi memberi pengaruh yang signifikan terhadap kepatuhan wajib pajak. Hal ini menunjukkan jika adanya sistem restrukturisasi organisasi kerja yang lebih baik seperti debirokratisasi, struktur organisasi berbasis fungsi terkait dengan perpajakan, dilakukan pemisahan antara fungsi pemeriksaan dengan fungsi keberatan, adanya segmentasi wajib pajak yang dikelola KPP, adanya internal audit serta efisiensi diharapkan dapat memberi kemudahan pada wajib pajak untuk patuh membayar pajak. Lebih lanjut hasil analisis menunjukkan jika indikator yang paling baik dalam membentuk variabel Restrukturisasi Organisasi $\left(\mathrm{X}_{1}\right)$ adalah $\mathrm{X}_{15}$ (Internal Audit) dengan loading faktor tertinggi sebesar 0,811 . Hal ini menunjukkan jika keberadaan internal audit yang kompeten akan membuat masyarakat percaya dengan pengelolaan dana dari masyarakat (pajak) dan akan meningkatkan kepatuhannya dalam membayar pajak. Hasil penelitian ini mendukung penelitian Candra et al (2013) dan Mentayani, et al (2015) yang menemukan jika restrukturisasi organisasi mempunyai pengaruh yang signifikan terhadap kepatuhan wajib pajak.

\section{Pengaruh Pemanfaatan Teknologi Informasi dan Komunikasi terhadap Kepatuhan Wajib Pajak}

Teknologi informasi merujuk pada seluruh bentuk teknologi yang digunakan 
untuk menciptakan, menyimpan, mengubah, dan menggunakan informasi dalam segala bentuknya.Pemanfaatan teknologi informasi dan komunikasi ini merupakan upaya yang mendukung perubahan yang berbasis pada modernisasi sistem administrasi perpajakan. Maka dari itu penerapan full automation dengan memanfaatkan teknologi informasi dan komunikasi, terutama dalam pelaksanaan pekerjaan akan menciptakan business process yang efisien dan efektif karena proses adminstrasi menjadi lebih cepat, mudah dan akurat sehingga dapat meningkatkan pelayanan terhadap wajib pajak baik dari segi kualitas maupun waktu. Hal ini didukung dengan hasil analisis yang menunjukkan jika indikator yang paling baik dalam membentuk variabel Pemanfaatan TIK $\left(\mathrm{X}_{2}\right)$ adalah indikator berbasis teknologi informasi $\left(\mathrm{X}_{21}\right)$ dengan loading faktor tertinggi sebesar 0,914 .

Hasil penelitian ini juga didukung oleh hasil penelitian terdahulu bahwa semakin tinggi tingkat pemanfaatan teknologi informasi akan mempengaruhi efektivitas sistem informasi yang dihasilkan kehadiran teknologi merupakan sumber kekuatan yang menjadikan sebuah organisasi memiliki keunggulan yang kompetitif, serta diidentifikasikan sebagai faktor yang memberikan retribusi terhadap keberhasilan organisasi (Putra dkk, 2014). Hasil analisis juga menunjukkan bahwa pemanfaatan teknologi informasi dan komunikasi memberi nilai paling besar terhadap pelaksanaan modernisasi system administrasi perpajakan guna mem-pengaruhi kepatuhan wajib pajak. Selainitu proses administrasi melalui system yang ada akan meningkatkan kepercayaan masyarakat. Hasil penelitian ini mendukung penelitian Palupi (2010) serta Sudrajat dan Omposungguh (2015) yang menemukan pengaruh dan pentingnya pemanfaatan tehnologi informasi dan komunikasi terhadap kepatuhan wajib pajak.

\section{Pengaruh Penyempurnaan Sumber Daya Manusia terhadap Kepatuhan Wajib Pajak}

Penyempurnaan sumber daya manusia merupakan salah satu modernisasi sistem administrasi perpajakan yang dilakukan oleh KPP. Penyempurnaan sumber daya manusia merupakan kunci utama keberhasilan reformasi karena elemen terpenting dari organisasi terletak pada sumber daya manusianya, secanggih dan sehebat apapun organisasi kalau tidak didukung dengan sumber daya manusia yang berintegritas dan mempunyai kompetensi yang tinggi maka lambat laun akan mengalamin kemunduran dan bahkan hancur. Tujuan dari penyempurnaan sumber daya manusia adalah untuk meningkatkan kinerja dari karyawan kantor pajak sehingga berimbas pada peningkatan pelayanan yang baik pada wajib pajak sehingga meningkatkan kepatuhan wajib pajak.

Peningkatan dan penyempurnaan kemampuan sumber daya manusia dalam modernisasi system perpajakan dititikberatkan pada kompetensi staf terutama dalam memberikan pelayanan pada masyarakat sebagai wajib pajak serta perbaikan dan peningkatan yang dilakukan secara terus menerus dan berkesinambungan. Hal ini didukung dengan hasil analisis yang menunjukkan jika indikator yang paling baik dalam membentuk variabel Penyempurnaan $\mathrm{SDM}\left(\mathrm{X}_{3}\right)$ adalah $\mathrm{X}_{32}$ (Customer Driven) dengan loading faktor tertinggi sebesar 0,842 . Dengan demikian dapat dikemukakan jika pada intinya penyempurnaan staf DJP bertujuan untuk mempercepat perwujudan pelayanan public yang prima dengan membenahi kualitas kinerja aparaturnya. Hasil ini mendukung penelitian Palupi (2010) yang menunjuk-kan jika penyempurnaan sumber daya manusia berpengaruh positif dan signifikan terhadap kepatuhan wajib pajak 


\section{KESIMPULAN DAN SARAN}

Hasil penelitian menunjukkan jika restrukturisasi organisasi mempunyai pengaruh positif terhadap kepatuhan wajib pajak. Pengaruh positif menunjukkan bahwa semakin baik pola administrasi perpajakan yang berorientasi pada pelayanan terhadap wajib pajak di KPP Pratama Malang Utara seperti sistem administrasi yang sederhana dan mempermudah wajib pajak melakukan kewajibannya akan meningkatkan kepatuhan wajib pajak. Pemanfaatan teknologi informasi dan komunikasi mempunyai pengaruh positif signifikan terhadap kepatuhan wajib pajak. Hasil analisis menunjukkan jika pemanfaatan teknologi informasi dan komunikasi modern dalam system adminstrasi perpajakan yang semakin baik akan membuat pelayanan terhadap wajib pajak makin efektif dan efisien sehingga akan meningkatkan kepatuhan wajib pajak. Penyempurnaan sumber daya manusia mempunyai pengaruh positif signifikan terhadap kepatuhan wajib pajak. Hasil penelitian ini menunjukkan jika peningkatan kinerja sumber daya manusia pada Kantor Pelayanan Pajak Pratama Malang Utara akan meningkatkan kepatuhan wajib pajak. Dengan aparatur yang professional dan berkompeten sesuai tuntutan perubahan termasuk di dalamnya sebagai aparatur yang mampu memberikan pelayanan yang prima dan berkompeten pada masyarakat akan membuat masyarakat percaya dan mau membayar pajak.

Studi ini memiliki beberapa keterbatasan. Pertama, sampel dalam penelitian ini terbatas pada wajib pajak perorangan pada KPP Pratama Malang Utara. Hasil yang berbeda mungkin akan diperoleh jika sampel atau responden diperluas. Banyaknya jumlah sampel yang dibutuhkan dengan waktu penelitian yang terbatas membuat peneliti tidak bisa mengorek informasi lebih mendalam dan bagi responden sendiri mungkin mengisi kuesioner dengan cepat tanpa membaca dan memahami dengan teliti mengenai pertanyaan-pertanyaan dalam kuesioner. Penelitian selanjutnya hendaknya lebih memperhatikan cara penyebaran kuesioner agar lebih tepat dan efektif untuk memperoleh data.

Hasil penelitian merupakan persepsi responden pada saat pengambilan data dari responden, sehingga bisa terjadi perubahan setiap saat untuk situasi dan kondisi yang berbeda terutama yang berkaitan dengan variabel yang dikaji. Penelitian ini terbatas meneliti pengaruh restrukturisasi organisasi, pemanfaatan teknologi informasi dan komunikasi serta penyempurnaan SDM terhadap kepatuhan wajib pajak perorangan, maka penelitian selanjutnya mungkin dapat meneliti lebih lanjut mengenai dampaknya terhadap penerimaan pajak daerah

\section{DAFTAR PUSTAKA}

Artiningsih. (2013). Pengaruh Kesadaran Wajib Pajak Badan dan Pelayanan Perpajakan terhadap Kepatuhan Wajib Pajak di KPP Pratama Sleman. Program Studi Akuntansi-S1 Universitas Negeri Yogyakarta.

Candra Ricki, Wibisono Haris dan Mujilan. (2013). Modernisasi Sistem Administrasi Perpjakan dan Kepatuhan Wajib Pajak.Jurnal Riset Manajemen dan Akuntansi.Vol.I No.I Februari 2013.

Fauzi, Muhammad. (2009). Pengaruh Reformasi Struktur Organisasi Terhadap Peningkatan Pajak Pada Kanwil DJP Jakarta Timur.Tesis. UI

Gunadi.(2004). "Rasionalitas Reformasi Administrasi Perpajakan” http :// www. Infopajak.om.Htm

Hardika, Nyoman Sentosa.(2006). Pengaruh Lingkungan dan Individu Wajib Pajak terhadap Kepatuhan Wajib Pajak pada Hotel Berbintang di Propinsi Bali.Desertasi Universitas Airlangga Surabaya.

Iriyanto Y.(2009). Pengantar Ilmu Pajak Kebijakan dan Implementasi di Indonesia.Jakarta: Rajawali Pers

Jogiyanto dan Willy Abdillah. (2011). Sistem

Tata Kelola Teknologi Informasi. Yogyakarta: ANDI. 
Kristina. A. (2009). Pengembangan SDM Aparatur melalui Pendekatan Soft HRM sebagai Titik Tumpu Reformasi Perpajakan. Fakultas Ekonomi. Universitas Trunojoyo. Disampaikan dalam Simposium Nasional Perpajakan 2.

Masyur, H., (2013). Pengaruh Sistem Administrasi Perpajakan Modern terhadap Kepatuhan Wajib Pajak. Jurnal Ilmu Manajemen \& Bisnis, Vol. 04, No. 01. Maret 2013

Mentayani, Rusmanto dan Mail.(2015). Pengaruh Modernmisasi Sistem perpajakan terhadap Kepatuhan Wajib Pajak pada Kantor Pelayanan Penyuluhan dan Konsultasi Perpajakan di Kabupaten Hulu Dungai Utara Propinsi Kalimantan Selatan.Jurnal Ekonomi dan Bisnis Vol. 8. No. 2 September 2015

Mustikasari, Elia. (2007). Kajian Empriris Tentang Kepatuhan Wajib pajak Badan di Perusahaan Industri Pengolahan di Surabaya.Simposium Nasional Akuntansi X, Universitas Hasanudin Makassar.

Nasucha Chaizi, (2004). Reformasi Adminsitrasi Publik Teori dan Praktek. Jakarta: Penerbit Grasindo

Palupi Endah. (2010). Pengaruh Penerapan Sistem Administrasi Perpajakan Modern terhadap Kepatuhan Wajib Pajak dan Penerimaan Pajak Penghasilan Orang Pribadi pada Kantor Pelayanan Pajak Pratama Jakarta Gambir Empat. Tesis. Jakarta: Universitas Indonesia

Pandiangan Liberti, (2008). Modernisasi dan Reformasi Pelayanan Perpajakan. Jakarta: Penerbit PT. Alex Media Komuputindo

Putra, Dirgayusa Sukma 2014. Pengaruh Pengetahuan Karyawan bagian Akuntansi dan Pemanfaatan Teknologi Informasi terhadap Efektivitas Sistem Informasi Akuntansi.Jurnal Akuntansi Universitas Pendidikan Ganesha Vol 2 No. 1.
Rahayu,Sri dan Lingga, Salsalina, Ita.(2009). Pengaruh Modernisasi Sistem Administrasi Perpajakan terhadap Kepatuhan Wajib Pajak Badan pada KPP Pratama Bandung "X". Jurnal Akuntansi. Vol. 1, No. 2 November 2009: $119-138$

Sudrajat A dan Ompusdinggu. (2015). Pemanfaatan Teknologi Informasi, Sosialisasi Pajak, pengetahuan Perpajakan dan Kepatuhan Pajak. Jirnal Riset Akuntansi dan perpajakan.JRAP Vol. 2 No. 2 Sedember 2015. Hal 193202

Suandy, Erly (2003). Perenanaan Pajak, Salemba Empat, Jakarta

Sugiyono.(2012). Metode Penelitian Kuantitatif, Kualitatif dan $\mathrm{R}$ \& D. Bandung: CV. Alfabeta

Susanti, Erni Zirman dan Diyanto Volta. (2014). Pengaruh Wajib Pajak, Kepatuhan Wajib Pajak Badan dan Pemeriksaan terhadap Penerimaan Pajak Penghasilan Badan Pasal 25/29 pada Kantor Pajak Pratama Tampan Pekanbaru. Jom FEKON Vol.1 No 2 Oktober 2014

Suyanto.M, (2005).Pengantar Teknologi Informasi untuk Bisnis. Yogyakarta; Penerbit ANDI

Torgler, B.(2007),Tax Compliance and Tax Morale A Theoretical and Empirical Analysis. Cheltenham, UK: Northampton, MA, USA.

Trisnawati.(2015). Analisis Faktor Yang Mempengaruhi Kepatuhan Wajib Pajak Membayar Pajak Hotel, Pajak Restoren Dan Pajak Hiburan di Kota Denpasar. Tesis

Widayati dan Nurlis.(2010). Faktor-faktor yang Mempengaruhi Kemauan untuk Membayar Pajak Wajib Pajak Oranmg Pribadi yang Melakukan Pekerjaan Bebas (Studi Kasus pada KPP Pratama Gambir Tiga).Jurnal Publikasi SNA XIII Purwokerto 